Article

\title{
Isolation and Characterization of an Aerobic Denitrifier Bacillus sp. SC16 from an Intensive Aquaculture Pond
}

\author{
Chi-Guo Sang ${ }^{\dagger}$, Yao-Wu Fu ${ }^{\dagger}$, Shu-Quan Guo, Jia-Ju Luo and Qi-Zhong Zhang * \\ Key Laboratory of Eutrophication and Red Tide Prevention of Guangdong Higher Education Institutes, \\ Engineering Research Center of Tropical and Subtropical Aquatic Ecological Engineering, Department of \\ Ecology, Institute of Hydrobiology, School of Life Science and Technology, Ministry of Education, \\ Jinan University, West 601 Huangpu Avenue, Tianhe District, Guangzhou 510632, China; \\ sangchiguo@stu2017.jnu.edu.cn (C.-G.S.); fuyaowu9696@163.com (Y.-W.F.); \\ guoshuquan@stu2017.jnu.edu.cn (S.-Q.G.); luojia@stu2017.jnu.edu.cn (J.-J.L.) \\ * Correspondence: zhangqzdr@126.com; Tel.: +86-20-85225808 \\ + These authors contributed equally to this work.
}

Received: 21 November 2020; Accepted: 12 December 2020; Published: 18 December 2020

check for updates

\begin{abstract}
Overloading of ammonia and nitrite nitrogen in aquaculture can result in toxicity to aquatic animals. In order to eliminate the hazardous substances, a highly efficient denitrifying bacterium, Bacillus sp. SC16, was identified in a fishery pond and isolated subsequently. The strain SC16 could remove nitrate up to $97 \%$, ammonia up to $36.6 \%$, and nitrite up to $99.99 \%$ when incubated with nitrate at an initial concentration of $306.9 \mathrm{mg} \cdot \mathrm{L}^{-1}$ for $72 \mathrm{~h}$, ammonia at $165.49 \mathrm{mg} \cdot \mathrm{L}^{-1}$ for $48 \mathrm{~h}$, and nitrite at $200 \mathrm{mg} \cdot \mathrm{L}^{-1}$ for $24 \mathrm{~h}$ under aerobic conditions. The nitrite reductase gene was identified as the nirK gene. The transcriptional levels of the nirK gene in strain SC16 incubated with ammonia, nitrate, and nitrite showed similar expression patterns. When the strain SC16 was used to treat the aquaculture water, the concentration of ammonia decreased significantly, from $8.35 \mathrm{mg} \cdot \mathrm{L}^{-1}$ to $4.56 \mathrm{mg} \cdot \mathrm{L}^{-1}$, and there was almost no accumulation of nitrite by the end of experiment. Therefore, the results indicated that Bacillus sp. SC16 could be a promising candidate for aquaculture water treatment.
\end{abstract}

Keywords: Bacillus sp.; denitrification; nirK gene; transcriptional expression; aquaculture

\section{Introduction}

During the past two decades, the total production of farmed fish in China increased three-fold, with the greatest contribution coming from fresh water aquaculture (25.4 million metric tons in 2018) [1,2]. To achieve such a high yield, an intensive feed-driven culture model was implemented by fishery farmers. However, this intensive culture model has resulted in the accumulation of nitrogenous pollutants due to the aquafeed residues and feces, thereby causing environmental concerns, such as eutrophication, algae blooms, and water contamination [3,4]. The nitrogen-enriched aquaculture water discharged into adjacent rivers might result in eutrophication and thus affect the aquatic ecosystems. Therefore, there is a need to improve aquaculture water through decreasing the accumulation of nitrogenous pollutants.

Many conventional techniques, e.g., rotating biological contactors, trickling filters, bead filters, and fluidized sand biofilters, have been applied to remove the nitrogen from water [5]. In addition, biological treatments, including the bio-flocs technology and microbiological method, have also attracted wide attention due to their simple operation, lower maintenance costs, and high pollutant-removal efficiency [5,6]. Aerobic denitrifiers, also named as heterotrophic nitrification and aerobic denitrification (HN-AD) bacteria [7], combine the processes of both nitrification and denitrification. The bacteria are 
potential candidates in bioremediation due to their high removal rate of nitrogen [8]. Aerobic denitrifiers belonging to different species have been screened and characterized, for example, Pseudomonas putida [9], Alcaligenes faecalis [10], Thiosphaera pantotropha [11], Rhodococcus sp. [6], and Bacillus subtilis [12]. Nevertheless, there are limited aerobic denitrifiers used to treat intensive aquaculture water [13]. Thus, it is still necessary to find bacterial organism with high nitrogen-removal efficiency to eliminate nitrogen contamination in aquaculture.

Aerobic denitrification is considered as the assemblage of $\mathrm{NO}_{3}^{-}$respiration, $\mathrm{NO}_{2}^{-}$respiration, $\mathrm{NO}$ reduction, and $\mathrm{N}_{2} \mathrm{O}$ respiration: $\mathrm{NO}_{3}^{-} \rightarrow \mathrm{NO}_{2}^{-} \rightarrow \mathrm{NO} \rightarrow \mathrm{N}_{2} \mathrm{O} \rightarrow \mathrm{N}_{2}$ [14]. The four consecutive steps are catalyzed by nitrate reductase (NAR), nitrite reductase (NIR), nitric oxide reductase (NOR), and nitrous oxide reductase (NOS), respectively [15]. Nitrite respiration, the key process in aerobic denitrification, is catalyzed by NIR, the enzyme that determines the denitrification properties of bacteria [16]. A high activity of nitrite reductase results in a high efficacy of nitrite respiration, as the enzyme makes aerobic denitrifying strains use nitrite preferentially. The inefficiency, impaired activity, and lack of nitrite reductase in some denitrifiers would cause the strains to lose the capability of complete denitrification and result in the accumulation of nitrite [17]. There are commonly two types of NIR in denitrifiers, copper nitrite reductase and cytochrome cd1 nitrite reductase encoded by nirK and nirS genes, respectively. It has been reported that nirS and nirK don't usually coexist in denitrifiers [18].

The present study aimed to investigate the performance of Bacillus sp. SC16 isolated from a high-density culture pond in eliminating nitrogen under aerobic conditions. Our objectives were to clone the nitrite reductase gene and assess the expression levels of nitrite reductase genes using real-time PCR when strain SC16 was incubated with nitrate, ammonium, or nitrite.

\section{Materials and Methods}

\subsection{Media}

The basal medium of denitrifying medium (DM) contained the following components per liter [19]: $\mathrm{CH}_{3} \mathrm{COONa} 2.0 \mathrm{~g}, \mathrm{MgSO}_{4} \cdot 7 \mathrm{H}_{2} \mathrm{O} 0.6 \mathrm{~g}, \mathrm{CaCl}_{2} \cdot 2 \mathrm{H}_{2} \mathrm{O} 0.07 \mathrm{~g}, \mathrm{KH}_{2} \mathrm{PO}_{4} 0.4 \mathrm{~g}$, trace elements $1 \mathrm{~mL}$, and Tris buffer $12 \mathrm{~mL}$. The trace elements per liter was composed of $\mathrm{ZnSO}_{4} 2.2 \mathrm{~g}, \mathrm{FeSO}_{4} \cdot 7 \mathrm{H}_{2} \mathrm{O} 3.0 \mathrm{~g}, \mathrm{CaCl}_{2} 5.5 \mathrm{~g}$, $\mathrm{MnCl}_{2} \cdot 4 \mathrm{H}_{2} \mathrm{O} 5.0 \mathrm{~g}, \mathrm{CuSO}_{4} \cdot 5 \mathrm{H}_{2} \mathrm{O} 1.6 \mathrm{~g}, \mathrm{CoCl}_{2} \cdot 6 \mathrm{H}_{2} \mathrm{O} 1.6 \mathrm{~g}$, and $\left(\mathrm{NH}_{4}\right)_{6} \mathrm{Mo}_{7} \mathrm{O}_{24} \cdot 4 \mathrm{H}_{2} \mathrm{O} 1.1 \mathrm{~g}$. The Tris buffer (per liter) contained $121.1 \mathrm{~g} \mathrm{C}_{4} \mathrm{H}_{11} \mathrm{NO}_{3} . \mathrm{KNO}_{3} 0.5 \mathrm{~g}, \mathrm{NH}_{4} \mathrm{Cl} 0.5 \mathrm{~g}$, and $\mathrm{NaNO}_{2} 0.3 \mathrm{~g}$ were added into the DM to form the media DM-1, DM-2 and DM-3, respectively. The ingredients of BTB per liter were as follows: L-Asparagine $10.0 \mathrm{~g}, \mathrm{KNO}_{3} 1.0 \mathrm{~g}, \mathrm{KH}_{2} \mathrm{PO}_{4} 1.0 \mathrm{~g}, \mathrm{FeCl}_{2} \cdot 6 \mathrm{H}_{2} \mathrm{O} 0.05 \mathrm{~g}, \mathrm{CaCl}_{2} \cdot 2 \mathrm{H}_{2} \mathrm{O}$ $0.2 \mathrm{~g}, \mathrm{MgSO}_{4} \cdot 7 \mathrm{H}_{2} \mathrm{O} 1.0 \mathrm{~g}$, and BTB regent $(1 \%(w / v))$ in alcohol $1 \mathrm{~mL}$. Luria-Bertani (LB) medium used for seed preparation and culture preservation contained $10 \mathrm{~g} \mathrm{~L}^{-1}$ of peptone, $5 \mathrm{~g} \mathrm{~L}^{-1}$ of yeast extract, and $10 \mathrm{~g} \mathrm{~L}^{-1}$ of $\mathrm{NaCl}$. The $\mathrm{pH}$ of all media was adjusted to 7.0 . The agar at $2 \%(w / v)$ was added in liquid media to prepare the solid media. All media were autoclaved for $20 \mathrm{~min}$ at $121^{\circ} \mathrm{C}$, followed by adding BTB regent.

\subsection{Isolation and Identification}

The sludge samples were obtained from intensive aquaculture ponds in the Huadu district, Guangzhou, China. First, several $500 \mathrm{~mL}$ vitreous flasks containing $5 \mathrm{~mL}$ of the sludge sample and $100 \mathrm{~mL}$ DM were transferred to a rotary shaker (WSQ; SCIENTZ Co., Ltd., Ningbo, China) with $200 \mathrm{rpm}$ at $28^{\circ} \mathrm{C}$ for $3 \mathrm{~d}$. Next, $5 \mathrm{~mL}$ of the bacteria solution was inoculated into $100 \mathrm{~mL} \mathrm{DM}$ and cultured under the same conditions as described above, repeating once to enrich denitrifying bacteria. Then, the bacteria solution was diluted using 10-fold serial dilutions to concentrations of $10^{-3}, 10^{-4}, 10^{-5}$, and $10^{-6}$. After dilution, $0.1 \mathrm{~mL}$ bacterial suspension of each concentration was inoculated on solid $\mathrm{BTB}$, followed by incubating at $28^{\circ} \mathrm{C}$ for $2 \mathrm{~d}$. Denitrifying bacteria showed blue colonies on the solid BTB. Thus, the blue colonies were selected and purified. Finally, the purified colonies were suspended in $40 \%$ sterile glycerol solution $(v / v)$ and then stored at $-80{ }^{\circ} \mathrm{C}$ for further analysis. 
The morphology of the strain isolated was examined using a scanning electron microscope (SEM) (XL-30ESEM; PHILIPS Co., Ltd., Amsterdam, The Netherlands) at $24 \mathrm{~h}$ post-cultivation. Genomic DNA of the strain was extracted using a DNA extraction kit (Rapid Bacterial Genomic DNA Isolation Kit, Sangon Biotech Co., Ltd., Shanghai, China) according to the manufacturer's instructions. The $16 \mathrm{~S}$ rRNA gene was amplified using a PCR thermal cycler (Veriti ${ }^{\circledR}$ Thermal Cycler, ThermoFisher Co., Ltd., Waltham, MA, USA) with the general primers 27F and 1492R (in Supplementary, Table S1). Reaction mixtures with a final volume of $25 \mu \mathrm{L}$ contained each of the primers $\left(10 \mu \mathrm{mol} \mathrm{L}{ }^{-1}\right), 2.5 \mathrm{mM}$ dNTPs, 10 reaction buffer, $2.5 \mathrm{U}$ Taq polymerase (TaKaRa Co., Ltd., Kyoto, Japan), $1 \mu \mathrm{g}$ DNA template, and double-distilled water $\left(\mathrm{ddH}_{2} \mathrm{O}\right)$. PCR was conducted with the following conditions: 4 min at $94{ }^{\circ} \mathrm{C}$ for pre-denaturation, 35 cycles of $10 \mathrm{~s}$ at $98{ }^{\circ} \mathrm{C}$ for denaturation, $30 \mathrm{~s}$ at $54{ }^{\circ} \mathrm{C}$ for annealing, $1 \mathrm{~min}$ at $68{ }^{\circ} \mathrm{C}$ for extension, and $7 \mathrm{~min}$ at $68^{\circ} \mathrm{C}$ for final extension. The PCR product was sequenced by BGI Genomics Co., Ltd. (Shenzhen, Guangdong, China). The partial sequence was analyzed and compared with that of other strains obtained from the NCBI database using the Basic Local Alignment Search Tool (BLAST). A phylogenetic tree was constructed using the maximum-likelihood method implemented in the MEGA 6.0 software (MEGA software development team, Phoenix, AZ, USA), with 1000 bootstrap replicates.

\subsection{Nitrogen Removal Performance}

The optimum incubation conditions for growth and nitrogen removal performance of strain SC16 was determined with single-factor experiments. The basal conditions were assigned as follows: $\mathrm{KNO}_{3}$ concentration of $500 \mathrm{mg} / \mathrm{L}$, temperature of $28^{\circ} \mathrm{C}$, rotation of $200 \mathrm{rpm}$, and $1 \%$ inoculation $(\mathrm{v} / \mathrm{v})$. For carbon resources, sodium acetate, citric acid, glucose, ethanol, and methanol were selected. For $\mathrm{C} / \mathrm{N}$ ratios, 1, 2, 4, 8, 16, and 32 were set. For the $\mathrm{pH}$ experiment, the initial $\mathrm{pH}$ values of 5, 6, 7, 8, and 9 were adjusted. For the temperature experiment, $15^{\circ} \mathrm{C}, 20^{\circ} \mathrm{C}, 28^{\circ} \mathrm{C}$, and $37^{\circ} \mathrm{C}$ were designed. All of the tests were conducted with three replications, and non-seeded samples were used as blank controls.

To estimate the nitrogen removal ability of strain SC16, a single colony of the strain was transferred into $100 \mathrm{~mL}$ LB liquid medium and cultured in a rotary shaker with $200 \mathrm{rpm}$ at $28^{\circ} \mathrm{C}$ for $24 \mathrm{~h}$. The solution of bacteria was centrifuged at $4500 \times \mathrm{g}$ for $10 \mathrm{~min}$ at $4{ }^{\circ} \mathrm{C}$, followed by removing the supernatant, the sediment was washed three times with phosphate buffer. After washing, the bacteria were suspended with phosphate buffer, and then $2.5 \mathrm{~mL}$ of the bacterial solution was added into 250 mL DM-1, DM-2 and DM-3 medium.

The initial concentrations of nitrate in DM-1, ammonia in DM-2, and nitrite in DM-3 were 306.9, 165.49 , and $200 \mathrm{mg} \cdot \mathrm{L}^{-1}$, respectively. The conical flasks were incubated in a rotary shaker to supply oxygen with $200 \mathrm{rpm}$ at $28^{\circ} \mathrm{C}$. The medium without inoculation was used as a control. The $10 \mathrm{~mL}$ samples were taken from the flasks every $12 \mathrm{~h}$ and centrifuged at $6500 \times \mathrm{g}$ for $10 \mathrm{~min}$ at room temperature. The supernatant was taken to determine the optical density at $600 \mathrm{~nm}\left(\mathrm{OD}_{600}\right)$ to measure the concentrations of $\mathrm{NH}_{4}^{+}-\mathrm{N}, \mathrm{NO}_{3}^{-}-\mathrm{N}$, and $\mathrm{NO}_{2}^{-}-\mathrm{N}$. All of the assays were performed in triplicate. The formula of nitrogen removal rate was $\left(\mathrm{C}_{0}-\mathrm{C}_{\mathrm{n}}\right) / \mathrm{t}$, where $\mathrm{t}$ was the total time for strain SC16 treatment, $\mathrm{C}_{0}$ was the initial concentrations of $\mathrm{NH}_{4}^{+}-\mathrm{N}, \mathrm{NO}_{3}^{-}-\mathrm{N}$, and $\mathrm{NO}_{2}^{-}-\mathrm{N}$, as well as $\mathrm{C}_{\mathrm{n}}$ was the final concentrations at time $t$.

To study the $\mathrm{NO}_{2}^{-}-\mathrm{N}$ tolerance of strain $\mathrm{SC} 16, \mathrm{NaNO}_{2}$ was added into the DM to make initial nitrite concentrations of $0.1,2,50,100,200,250,300,500$, and $1000 \mathrm{mg} \cdot \mathrm{L}^{-1}$. SC16 was inoculated into these media, followed by incubating with $200 \mathrm{rpm}$ at $28{ }^{\circ} \mathrm{C}$ using a rotary shaker. The samples were collected as mentioned above, and the removal percentage was determined as follows: removal percentage $(\%)=100 \times($ initial total nitrite - final total nitrite $) /$ initial total nitrite.

\subsection{Enzyme Assay}

After cultivation in DM-1 medium for $24 \mathrm{~h}$, the medium was centrifuged at $3000 \times g$ for $10 \mathrm{~min}$ to obtain bacteria. Enzyme extracts were prepared by breaking bacterial cells applying ultrasonication as described by previous study [20]. (1) NAR activity trial: $20 \mathrm{~mL}$ reaction mixture contained $0.2 \mathrm{mM}$ 
$\mathrm{NADH}, 10 \mathrm{mM}$ potassium phosphate buffer, $10 \mu \mathrm{M} \mathrm{NaNO}$, and enzyme extracts; (2) NiR activity trial: $20 \mathrm{~mL}$ reaction mixture contained $0.2 \mathrm{mM} \mathrm{NADH}, 10 \mathrm{mM}$ potassium phosphate buffer, $10 \mu \mathrm{M}$ $\mathrm{NaNO}_{2}$, and enzyme extracts; (3) Ammonia monooxygenase (AMO) activity trial: $20 \mathrm{~mL}$ reaction mixture contained $10 \mathrm{mM}$ Tris/ $\mathrm{HCl}, 0.2 \mathrm{mM} \mathrm{NADH}, 10 \mu \mathrm{M} \mathrm{NH} \mathrm{N}_{4} \mathrm{Cl}$, and enzyme extracts. All of the trials were incubated at $28^{\circ} \mathrm{C}$ for $15 \mathrm{~min}$ with three repetitions, and a constant shaking of $120 \mathrm{rpm}$ was used for the AMO activity trial. The enzyme activities of NAR, NIR, and AMO were determined by the reduction of $\mathrm{NaNO}_{3}, \mathrm{NaNO}_{2}$, and $\mathrm{NH}_{4} \mathrm{Cl}$, respectively, according to previous study [20]. The Lowry method was used to determine the protein concentration in the bacteria extract [21]. The specific activity $\left(\mathrm{U} \mathrm{mg}^{-1}\right)$ was expressed as the amount of enzyme that catalyzed the transformation of $1 \mu \mathrm{mol}$ of substrate per minute by the amount of protein in milligrams [22].

\subsection{Amplification of the Functional Genes}

Fragments of the NIR encoding gene nirK (or nirS) were amplified using the primer pairs nirK1F-nirK5R and nirS1F-nirS6R (in supplementary, Table S1). PCR amplification was performed in a $25 \mu \mathrm{L}$ reaction mixture containing $2.5 \mu \mathrm{L} 10 \times$ PCR buffer for KOD-Plus-Neo, $1.5 \mu \mathrm{L}$ dNTP mixture $(2 \mathrm{mM}), 1.5 \mu \mathrm{L} \mathrm{MgSO}_{4}(25 \mathrm{mM}), 1 \mu \mathrm{L}$ F-primer $(10 \mu \mathrm{M}), 1 \mu \mathrm{L}$ R-primer $(10 \mu \mathrm{M}), 10-100$ ng DNA template, $1 \mathrm{U}$ KOD-Plus-Neo (Toyobo, Japan), and $15 \mu \mathrm{L} \mathrm{ddH}_{2} \mathrm{O}$. The PCR program included the following steps: $94{ }^{\circ} \mathrm{C}$ for $4 \mathrm{~min} ; 35$ cycles at $98^{\circ} \mathrm{C}$ for $10 \mathrm{~s}$, annealing temperature of $55^{\circ} \mathrm{C}$ for $30 \mathrm{~s}$, $68^{\circ} \mathrm{C}$ for $30 \mathrm{~s}$; and final extension of $68^{\circ} \mathrm{C}$ for $7 \mathrm{~min}$. The PCR products were sent to BGI Genomics Co., Ltd., (Shenzhen, Guangdong, China) for sequencing.

\subsection{Quantitative Real-Time PCR (QRT-PCR) Assay}

The expression levels of nitrite reductase genes in strain SC16 incubated with different nitrogen sources (DM-1, DM-2, and DM-3) were detected using QRT-PCR. Five milliliter samples were collected after $0,12,18,24,36,48,60$, and $72 \mathrm{~h}$ in DM-1 post cultivation. Similarly, $5 \mathrm{~mL}$ samples were collected after $0,6,12,18,24,36$, and $48 \mathrm{~h}$ in DM-2 and DM-3 post cultivation. Media with no nitrogen sources were used as controls. Total RNA of each sample was extracted with TRIZOL reagent according to the manufacturer's instructions (Cat. No.15596-026; Invitrogen) [23]. Then, the first complementary DNA (cDNA) was synthesized with M-MLV Reverse transcriptase (Promega) and oligo (dT) primer. A $20 \mu \mathrm{L}$ reaction mixture containing SYBR Green Real-time PCR Master Mix (Toyobo, Japan), cDNA, dd $\mathrm{d}_{2} \mathrm{O}$, and gene-specific primer pairs nir $K^{\#}$-F/nirK $K^{\#}$-R was prepared for QRT-PCR. Reaction mixtures with no reverse transcription were employed as negative controls. The $16 \mathrm{~S}$ rRNA (in supplementary, Figure S1) was used as the reference gene to normalize for differences of cDNA between samples. QRT-PCR was run on an iCycler iQ instrument (Bio-Rad, Hercules, CA, USA) following the manufacturer's instructions. The PCR protocol was as follows: initial denaturation at $95^{\circ} \mathrm{C}$ for $5 \mathrm{~min} ; 40$ cycles at $95^{\circ} \mathrm{C}$ for $30 \mathrm{~s}, 60^{\circ} \mathrm{C}$ for $15 \mathrm{~s}, 72{ }^{\circ} \mathrm{C}$ for $20 \mathrm{~s}$; and a gradient from $65^{\circ} \mathrm{C}$ to $95^{\circ} \mathrm{C}$ during $10 \mathrm{~min}$ with continuous detection. The cross-point values were analyzed using the iCycler software version 1.0 (Bio-Rad, Hercules, CA, USA). Three replications were carried out for the experiment under identical experimental conditions.

\subsection{The Performance of Strain SC16 in Aquaculture Water}

The water was collected from another intensive aquaculture pond in Guangzhou. The concentrations of $\mathrm{NH}_{4}^{+}-\mathrm{N}, \mathrm{NO}_{3}^{-}-\mathrm{N}$, and $\mathrm{NO}_{2}^{-}-\mathrm{N}$ in the aquaculture water were $8.35 \mathrm{mg} \cdot \mathrm{L}^{-1}$, $0.46 \mathrm{mg} \cdot \mathrm{L}^{-1}$, and $0.02 \mathrm{mg} \cdot \mathrm{L}^{-1}$, respectively, with a $\mathrm{pH}$ of 6.60 . A total of $84 \mathrm{~L}$ water was distributed into six $20 \mathrm{~L}$ tanks, with each tank containing $14 \mathrm{~L}$ water. The six tanks were randomly divided into treatment group and control group, and each group had three tanks. The treatment group was added with $140 \mathrm{~mL}$ of strain SC16 inoculum, and the control group was added with $140 \mathrm{~mL}$ autoclaved culture medium without any bacteria. The tanks were equipped with an aeration pump (XK32, Xinke Co., Ltd., Shanghai, China) to supply oxygen, and the water temperature was maintained at $28{ }^{\circ} \mathrm{C}$ during the experiment. 


\subsection{Analytical Methods}

The bacterial density was detected using spectrophotometry (EPOCH, BioTek ${ }^{\circledR}$ Instruments. Inc., Winooski, VT, USA) with a wavelength of $600 \mathrm{~nm}\left(\mathrm{OD}_{600}\right)$. Culture samples were filtered through a $0.45-\mu \mathrm{m}$ membrane filter after a centrifugation at $10,000 \times g$. The concentrations of $\mathrm{NH}_{4}^{+}-\mathrm{N}_{,} \mathrm{NO}_{2}^{-}-\mathrm{N}_{\text {, }}$ and $\mathrm{NO}_{3}^{-}-\mathrm{N}$ were detected with methods of the phenol disulfonic acid photometry, Nessler's reagent photometry, and N-(1-naphthalene)-diaminoethane photometry, respectively [24].

\subsection{Statistical Analysis}

All of the data shown in the tables and figures were expressed as the mean values ( \pm standard deviation (SD)). The data of QRT-PCR were calculated using the $2^{-\Delta \Delta C t}$ method. Statistical analyses were performed with independent-samples $\mathrm{T}$ tests and one-way ANOVA analysis using a statistical analysis system software package (SPSS 13.0, IBM, New York, NY, USA). Results were considered statistically significant when $p<0.05\left({ }^{*}\right)$ or $p<0.01\left({ }^{* *}\right)$.

\section{Results}

\subsection{Isolation and Identification of Strain SC16}

Denitrifying bacteria showed blue colonies on the BTB plates due to the reaction caused by the increasing $\mathrm{pH}$ during the denitrification process. In the preliminary screening study, 19 strains isolated from the sludge samples with blue colonies on solid BTB were selected for nitrogen removal tests. The strain SC16 (GDMCC, accession number: 60942) demonstrated the highest nitrogen removal ability. The colony of SC16 was oyster white, convex, opaque, and had neat edges, and the surface was smooth, moist, and shiny. The SC16 was a gram-positive strain with morphological characteristics of short rod-shaped single cells, and the body size of SC16 was about $2.0 \mu \mathrm{m} \times 0.5 \mu \mathrm{m}$ (length $\times$ width) (Figure 1).

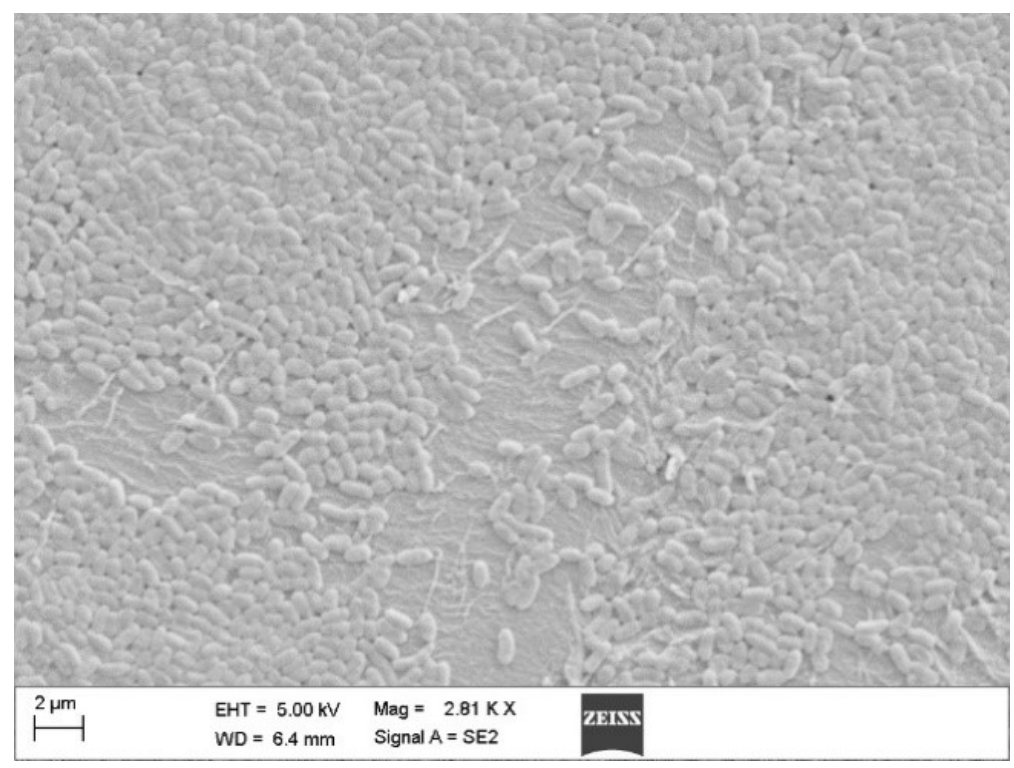

Figure 1. Single cell morphology of strain SC16 observed by SEM.

The obtained sequence of 16S rRNA gene was compared with other homologous sequences deposited in the NCBI database. The phylogenetic tree constructed using MEGA 6.0 (MEGA software development team, Phoenix, AZ, USA) is shown in Figure 2. Strain SC16 was clustered into a group with Bacillus velezensis QT-101 and showed 99\% homology with B. velezensis QT-101. The partial 16S rRNA nucleotide sequence was submitted to GenBank with the accession number MN620386. 


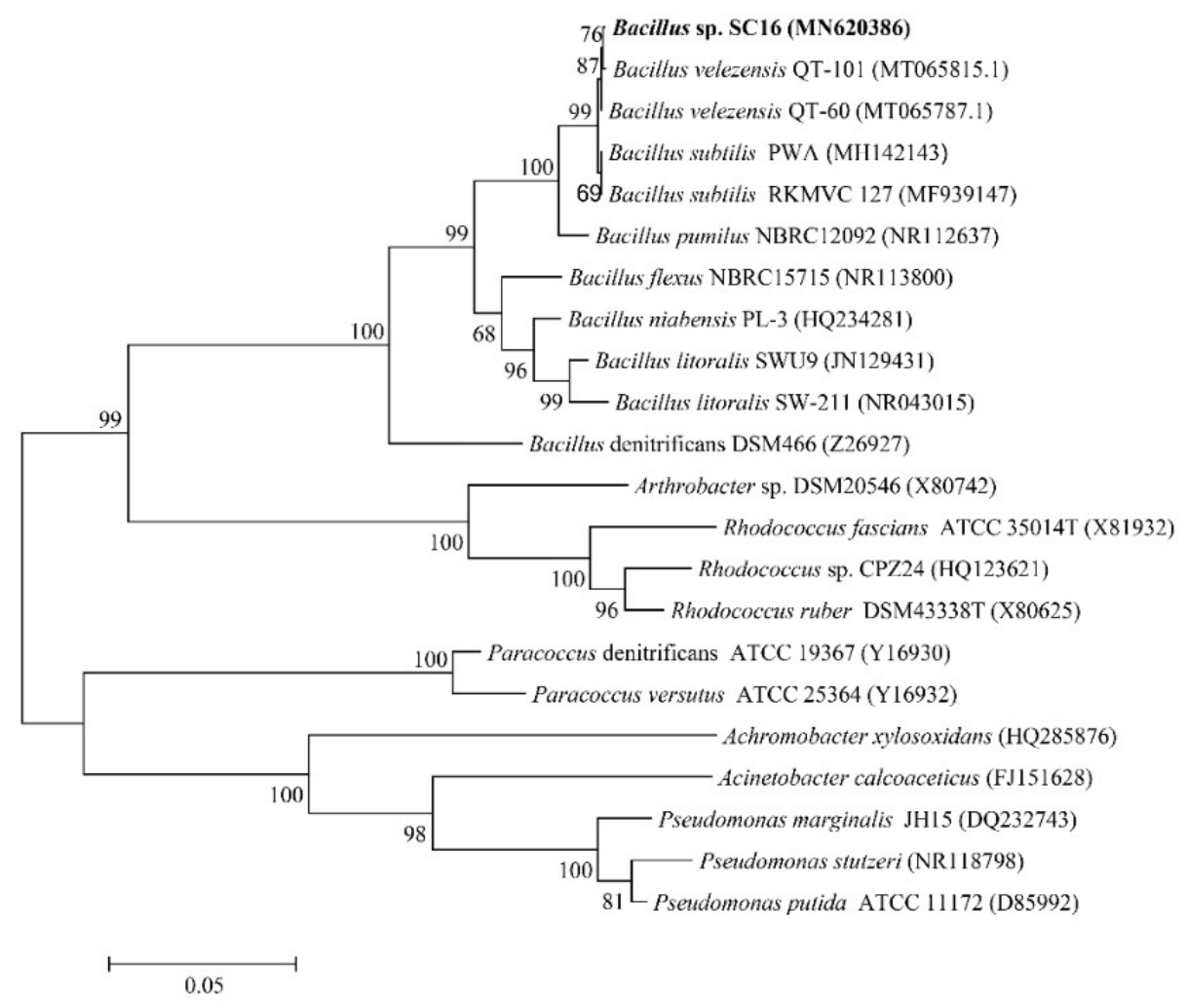

Figure 2. Phylogenetic tree of $16 \mathrm{~S}$ rRNA of strain SC16 and other strains was constructed using the maximum-likelihood method. Bootstrap values were calculated by 1000 repetitions; 0.02 denotes the genetic distance. The accession numbers of the GenBank sequences are shown in parentheses.

\subsection{Evaluation of Nitrogen Removal Ability of Strain SC16}

When $\mathrm{NO}_{3}^{-}-\mathrm{N}$ was used as the nitrogen source (Figure 3a), the concentration of $\mathrm{NO}_{3}^{-}-\mathrm{N}$ decreased significantly, from 306.9 to $46.99 \mathrm{mg} \cdot \mathrm{L}^{-1}$, with a removal rate of $20.50 \mathrm{mg} \cdot \mathrm{L}^{-1} \mathrm{~h}^{-1}$ after $12 \mathrm{~h}$ of cultivation. Then, an obvious lag period was observed from $24 \mathrm{~h}$ to $36 \mathrm{~h}$. The final removal efficiency of nitrate was $97 \%$, with a removal rate of $4.15 \mathrm{mg} \cdot \mathrm{L}^{-1} \mathrm{~h}^{-1}$ at $72 \mathrm{~h}$ post cultivation. The maximum concentration of $\mathrm{NO}_{2}^{-}-\mathrm{N}$ was $0.63 \mathrm{mg} \cdot \mathrm{L}^{-1}$, with a time to peak concentration of $24 \mathrm{~h}$, and then it decreased gradually from $24 \mathrm{~h}$ to $72 \mathrm{~h} . \mathrm{OD}_{600}$ increased slowly during the first $36 \mathrm{~h}$, then increased exponentially from $36 \mathrm{~h}$ to $48 \mathrm{~h}$ and subsequently entered into a stationary phase. The concentration of ammonium remained at a relatively low level during the trial.

When $\mathrm{NH}_{4}^{+}-\mathrm{N}$ was used as the nitrogen source, the concentration of $\mathrm{NH}_{4}^{+}-\mathrm{N}$ decreased from 165.49 to $104.85 \mathrm{mg} \cdot \mathrm{L}^{-1}$ in the initial $12 \mathrm{~h}$, with a removal rate of $5.05 \mathrm{mg} \cdot \mathrm{L}^{-1} \mathrm{~h}^{-1}$ and a removal efficiency of $36.6 \%$ (Figure 3c). The concentration of $\mathrm{NH}_{4}^{+}-\mathrm{N}$ maintained the same level from $12 \mathrm{~h}$ to the end of the incubation. The concentrations of $\mathrm{NO}_{3}^{-}-\mathrm{N}$ and $\mathrm{NO}_{2}^{-}-\mathrm{N}$ reached maximum values of $1.93 \mathrm{mg} \cdot \mathrm{L}^{-1}$ at $12 \mathrm{~h}$ and $0.31 \mathrm{mg} \cdot \mathrm{L}^{-1}$ at $24 \mathrm{~h}$, respectively; subsequently they decreased gradually to $0 \mathrm{mg} \cdot \mathrm{L}^{-1}$ at $48 \mathrm{~h}$. The $\mathrm{OD}_{600}$ increased from 0.045 at $0 \mathrm{~h}$ to the maximum value of 0.320 at $48 \mathrm{~h}$.

When nitrite was used as sole nitrogen source, the trend of cell growth was similar to that in the ammonium culture condition (Figure 3e). After $24 \mathrm{~h}$ incubation, the concentration of nitrite decreased significantly from $200 \mathrm{mg} \cdot \mathrm{L}^{-1}$ to $0.039 \mathrm{mg} \cdot \mathrm{L}^{-1}$, with the removal efficiency of $99.9 \%$ and the removal rate of $8.33 \mathrm{mg} \cdot \mathrm{L}^{-1} \mathrm{~h}^{-1}$. The concentration of $\mathrm{NO}_{3}^{-}-\mathrm{N}$ increased to $28.36 \mathrm{mg} \cdot \mathrm{L}^{-1}$ during the first $12 \mathrm{~h}$, and then it decreased to $5.66 \mathrm{mg} \cdot \mathrm{L}^{-1}$ at $48 \mathrm{~h}$. $\mathrm{No} \mathrm{NH}_{4}^{+}-\mathrm{N}$ was detected during the experiment.

Based on the single-factor experiments for the aerobic denitrification performance, the optimal culture conditions of strain $\mathrm{SC} 16$ were at $\mathrm{pH}$ of 7.0, carbon source of citric acid, $\mathrm{C} / \mathrm{N}$ ratio of 8 , and temperature of $28^{\circ} \mathrm{C}$ (in supplementary, Figure S2). 
(a)

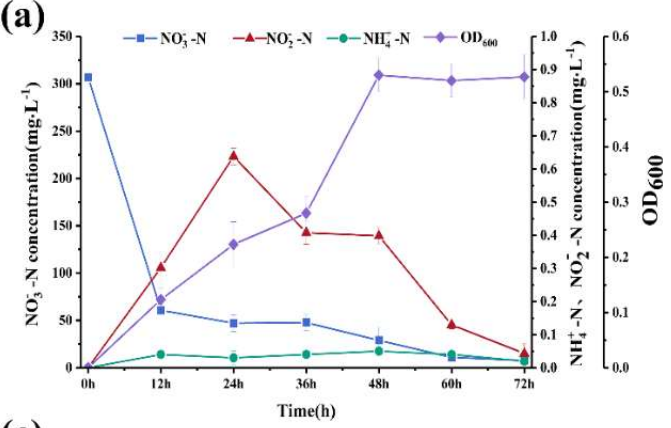

(c)

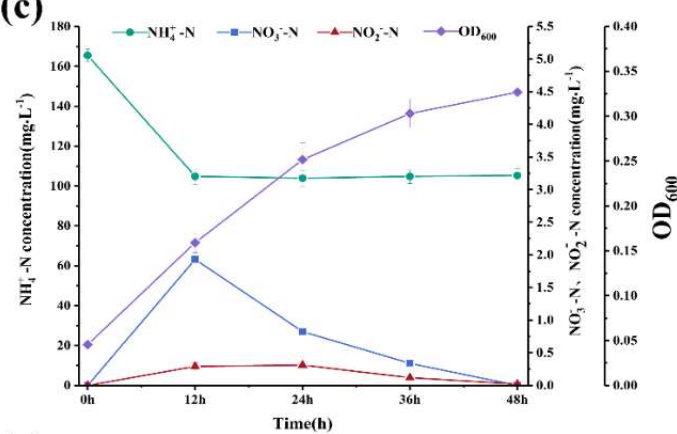

(e)

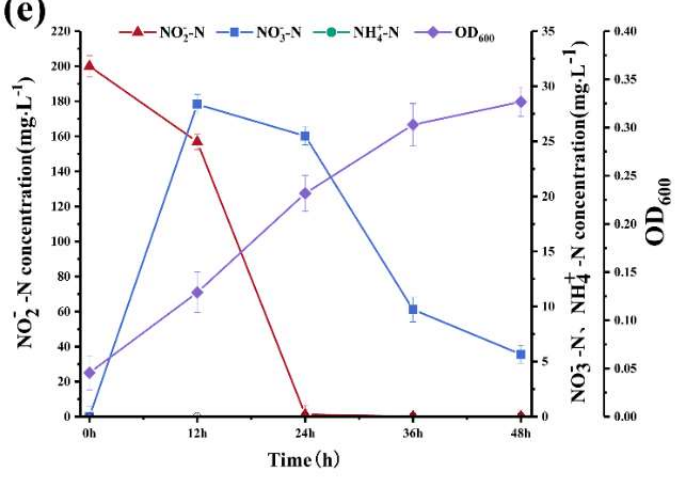

(b)

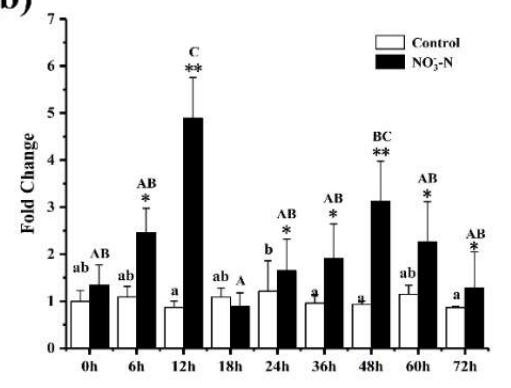

(d)

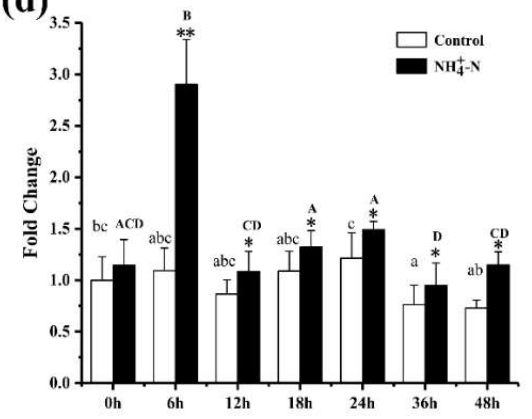

(f)

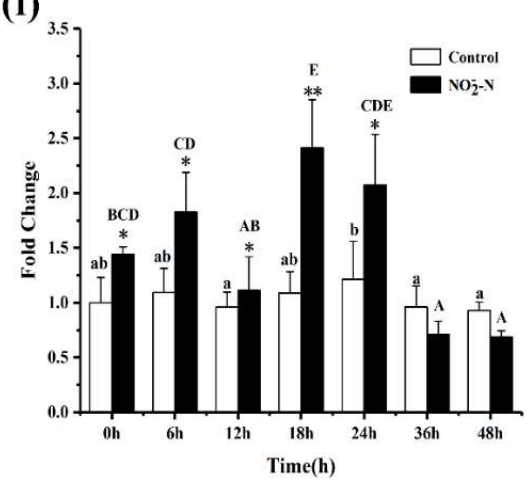

Figure 3. Nitrogen removal efficiency $(\mathbf{a}, \mathbf{c}, \mathbf{e})$ and transcriptional analysis $(\mathbf{b}, \mathbf{d}, \mathbf{f})$ of the nirK gene in denitrification medium (DM)-1, DM-2, and DM-3: $(\mathbf{a}, \mathbf{b})$ in DM-1 containing $306.9 \mathrm{mg} / \mathrm{L}$ of $\mathrm{NO}_{3}^{-}-\mathrm{N}$; (c and d) in DM-2 containing $165.49 \mathrm{mg} / \mathrm{L}$ of $\mathrm{NH}_{4}^{+}-\mathrm{N}$; (e,f) in DM-3 containing $200 \mathrm{mg} / \mathrm{L}$ of $\mathrm{NO}_{2}^{-}-\mathrm{N}$. All values are presented as the means $\pm S D(n=3)$. The values that are significantly different from the individual controls are present with asterisks $\left({ }^{*} p<0.05\right.$ and $\left.{ }^{* *} p<0.01\right)$. Values with different capital (lowercase) letters are significant differences among the experimental group (control group).

\subsection{Assessment of Nitrite Removal Performance of SC16 under Different Nitrite Concentrations}

A series of concentrations of $\mathrm{NO}_{2}^{-}-\mathrm{N}$ ranging from low concentrations of $0.1,2$, and $50 \mathrm{mg} \cdot \mathrm{L}^{-1}$ to high concentrations of $100,200,250,300,500$, and $1000 \mathrm{mg} \cdot \mathrm{L}^{-1}$ were added into DM to assess the nitrite removal performance by strain $\mathrm{SC} 16$. The unutilized nitrite and the $\mathrm{OD}_{600}$ were measured every $12 \mathrm{~h}$ after SC16 was cultured with $\mathrm{NO}_{2}^{-}-\mathrm{N}$. As shown in Figure 4, SC16 in the nitrite concentrations of 0.1, $2.0,50$, and $100 \mathrm{mg} \cdot \mathrm{L}^{-1}$ showed high growth rates under aerobic conditions. The $\mathrm{OD}_{600}$ in the nitrite concentration of $100 \mathrm{mg} \cdot \mathrm{L}^{-1}$ reached 1.0. The growth rate decreased significantly with the increasing of initial nitrite concentration; the $\mathrm{OD}_{600}$ values in the groups at concentrations of $200 \mathrm{mg} \cdot \mathrm{L}^{-1}$ and $250 \mathrm{mg} \cdot \mathrm{L}^{-1}$ were 0.63 and 0.29 , respectively. The strain SC16 showed no growth when the initial nitrite concentration was higher than $300 \mathrm{mg} \cdot \mathrm{L}^{-1}$. 


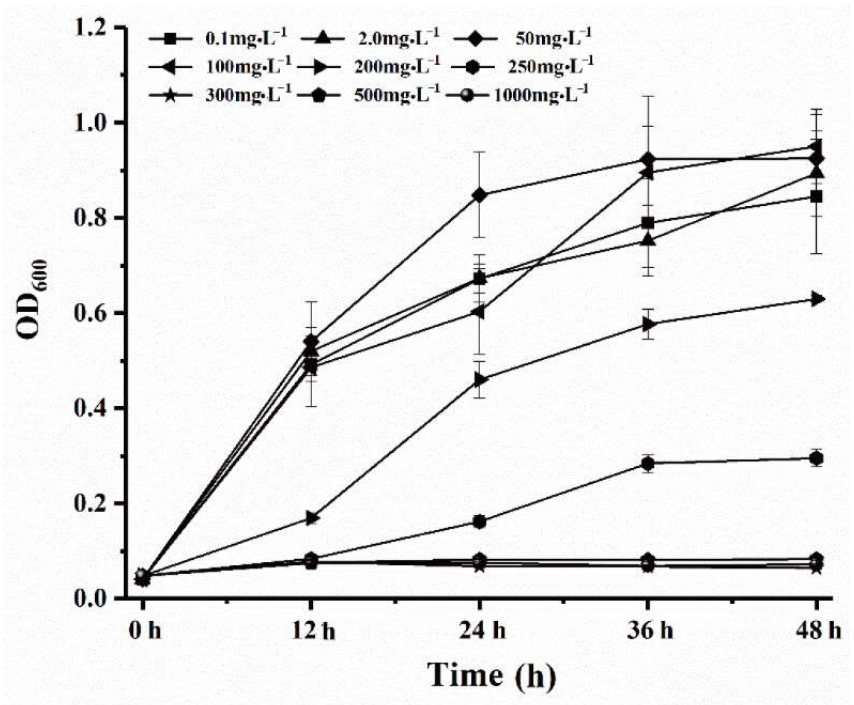

Figure 4. The growth curves of strain SC16 under different nitrite concentrations.

The nitrite utilization by SC16 showed a positive dose-response when the nitrite concentration ranged from 0.1 to $200 \mathrm{mg} \cdot \mathrm{L}^{-1}$, and it demonstrated a negative dose-response when nitrite concentrations were higher than $200 \mathrm{mg} \cdot \mathrm{L}^{-1}$ (Table 1). The removal rate increased from $90 \%$ at a concentration of $0.1 \mathrm{mg} \cdot \mathrm{L}^{-1}$ to $99.99 \%$ at a concentration of $200 \mathrm{mg} \cdot \mathrm{L}^{-1}$, while it decreased from $57.29 \%$ at a concentration of $250 \mathrm{mg} \cdot \mathrm{L}^{-1}$ to $6.78 \%$ at a concentration of $1000 \mathrm{mg} \cdot \mathrm{L}^{-1}$ (Table 1 ).

Table 1. The nitrite removal characteristics of Bacillus sp. SC16 under different nitrite concentrations.

\begin{tabular}{cccccccccc}
\hline \multirow{2}{*}{ Time (h) } & \multicolumn{7}{c}{ Nitrite Concentration $\left(\mathbf{m g} \cdot \mathbf{L}^{-\mathbf{1}}\right)$} \\
\cline { 2 - 10 } & $\mathbf{0 . 1}$ & $\mathbf{2}$ & $\mathbf{5 0}$ & $\mathbf{1 0 0}$ & $\mathbf{2 0 0}$ & $\mathbf{2 5 0}$ & $\mathbf{3 0 0}$ & $\mathbf{5 0 0}$ & $\mathbf{1 0 0 0}$ \\
\hline \multirow{2}{*}{0} & $0.091 \pm$ & $1.98 \pm$ & $49.52 \pm$ & $99.71 \pm$ & $199.76 \pm$ & $248.57 \pm$ & $297.25 \pm$ & $499.46 \pm$ & $992.96 \pm$ \\
& 0.03 & 0.088 & 0.29 & 0.19 & 6.39 & 3.29 & 5.58 & 17.26 & 11.17 \\
12 & $0.031 \pm$ & $0.043 \pm$ & $0.2 \pm$ & $0.71 \pm$ & $156.84 \pm$ & $200.48 \pm$ & $249.65 \pm$ & $438.24 \pm$ & $934.81 \pm$ \\
& 0.05 & 0.027 & 0.15 & 0.19 & 4.35 & 5.89 & 9.19 & 18.19 & 14.07 \\
24 & $0.02 \pm$ & $0.043 \pm$ & $0.1 \pm$ & $0.071 \pm$ & $1.29 \pm$ & $176.78 \pm$ & $246.89 \pm$ & $435.2 \pm$ & $933.62 \pm$ \\
& 0.05 & 0.058 & 0.17 & 0.17 & 1.19 & 1.58 & 7.13 & 16.52 & 13.32 \\
36 & $0.015 \pm$ & $0.04 \pm$ & $0.02 \pm$ & $0.07 \pm$ & $0.11 \pm$ & $138.76 \pm$ & $245.53 \pm$ & $434.34 \pm$ & $932.42 \pm$ \\
& 0.02 & 0.02 & 0.01 & 0.05 & 0.18 & 3.19 & 6.73 & 9.8 & 12.3 \\
48 & $0.01 \pm$ & $0.03 \pm$ & $0.015 \pm$ & $0.04 \pm$ & $0.039 \pm$ & $106.78 \pm$ & $240.89 \pm$ & $430.25 \pm$ & $932.23 \pm$ \\
& 0.03 & 0.02 & 0.011 & 0.02 & 0.02 & 2.79 & 9.87 & 11.23 & 10.02 \\
Removal ${ }^{\mathrm{a}}$ & $0.09 \pm$ & $1.97 \pm$ & $49.985 \pm$ & $99.96 \pm$ & $199.98 \pm$ & $143.22 \pm$ & $59.11 \pm$ & $69.75 \pm$ & $67.77 \pm$ \\
Removal & 0.03 & 0.02 & 0.011 & 0.02 & 0.02 & 2.79 & 9.87 & 11.23 & 10.02 \\
percentage & $90 \pm 0.3$ & $98.5 \pm$ & $99.97 \pm$ & $99.96 \pm$ & $99.99 \pm$ & $57.29 \pm$ & $19.7 \pm$ & $13.95 \pm$ & $6.78 \pm$ \\
$(\%) \mathrm{b}$ & & 0.01 & 0.00 & 0.00 & 0.00 & 0.01 & 0.03 & 0.02 & 0.01 \\
\hline
\end{tabular}

${ }^{a}$ Removal $=$ initial nitrite $\mathrm{N}-$ final nitrite $\mathrm{N} .{ }^{\mathrm{b}}$ Removal percentage $(\%)=100 \times$ (initial nitrite $\mathrm{N}-$ final nitrite $\mathrm{N})$ /initial nitrite $\mathrm{N}$.

\subsection{Enzyme Assay}

In order to further characterize the possible pathways involved in the process of nitrogen removal, the activities of AMO, NAR, and NIR of strain SC16 were detected under aerobic conditions. NIR demonstrated the highest activity of $0.0271 \pm 0.006 \mathrm{U} / \mathrm{mg}$ protein, followed by NAR with an activity of $0.026 \pm 0.008 \mathrm{U} / \mathrm{mg}$ protein and $\mathrm{AMO}$ with an activity of $0.0061 \pm 0.002 \mathrm{U} / \mathrm{mg}$ protein.

\subsection{Amplification of the Denitrification Genes}

nirK gene (GenBank accession number: MN918716) was cloned from the SC16 genome using the primers of nirK1F and nirK5R, while no fragment was cloned using the primers of nirS1F and nirS6R. 


\subsection{Effects of Nitrogen Sources on the Expression Level of Nitrite Reductase}

The transcriptional level of the nirK gene during the process of nitrogen removal was investigated to determine whether this gene was involved in denitrification. When nitrate was used as the nitrogen source, the mRNA expression of nirK was significantly up-regulated at $6 \mathrm{~h}$ post incubation $(p<0.05)$, and it reached the peak (4.89-fold) at $12 \mathrm{~h}$ post-incubation (Figure $3 \mathrm{~b}$ ). The expression of nirK decreased notably $(p<0.05)$ and demonstrated no significant difference compared with that of the control group at $18 \mathrm{~h}(p>0.05)$. Interestingly, the expression of nirK increased again from $24 \mathrm{~h}$ to $48 \mathrm{~h}$ and reached a second peak at $48 \mathrm{~h}$.

When SC16 was exposed to ammonium or nitrite, the mRNA expression pattern of nirK was similar to that of the nitrate treated group (Figure 3d,f). Both ammonium and nitrite resulted in a significant $(p<0.05)$ up-regulation of nirK gene expression, with double peaks during the $48 \mathrm{~h}$ of incubation. The maximum mRNA expression levels of nirK in the ammonium and nitrite treatment groups were 2.9-fold at $6 \mathrm{~h}$ (Figure 3d) and 2.4-fold at $18 \mathrm{~h}$ (Figure 3f).

\subsection{The Application of Strain SC16 in Aquaculture Water}

The treatment of strain SC16 on aquaculture water was conducted to investigate the practical application of the strain. As shown in Figure $5 \mathrm{a}, \mathrm{b}$, the initial $\mathrm{pH}$ of the water was $6.6 \pm 0.1$, and this increased gradually to $8.2 \pm 0.1$ and $8.3 \pm 0.05$ in the treatment group and control group, respectively. In the treatment group, the concentration of $\mathrm{NH}_{4}^{+}-\mathrm{N}$ decreased significantly from 8.35 to $4.56 \mathrm{mg} \cdot \mathrm{L}^{-1}$ with a removal efficiency of $45.3 \%$, and there was almost no accumulation of $\mathrm{NO}_{2}^{-}-\mathrm{N}$ at the end of experiment. In the control group, the concentration of $\mathrm{NH}_{4}^{+}-\mathrm{N}$ kept at a fluctuating level, and the concentration of $\mathrm{NO}_{2}^{-}-\mathrm{N}$ increased to $0.14 \mathrm{mg} \cdot \mathrm{L}^{-1}$.

(a)

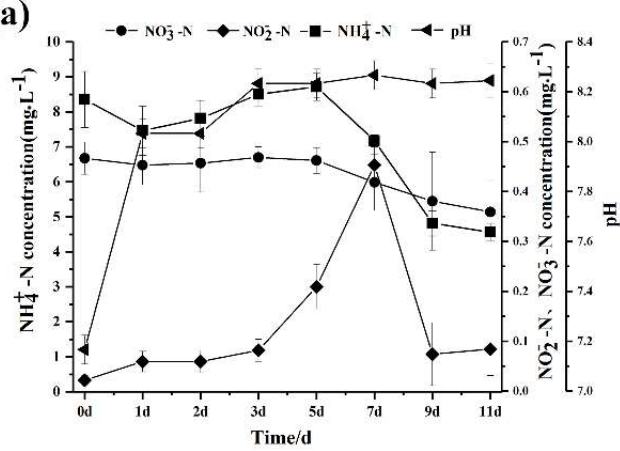

(b)

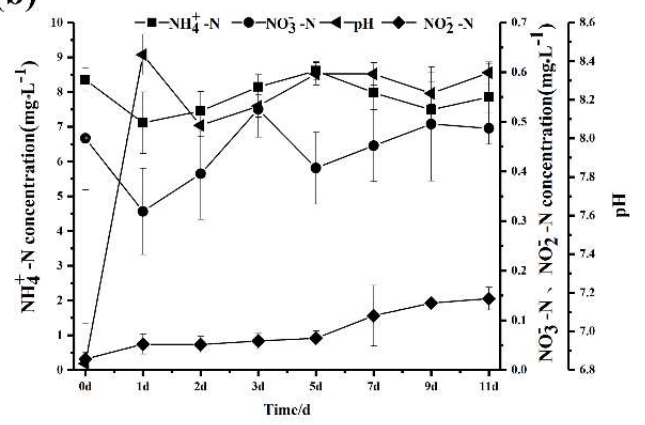

Figure 5. The nitrogen removal performance by strain SC16 in aquaculture water ((a): the treatment group; (b): the control group).

\section{Discussion}

Aerobic denitrifying bacteria with the capability of eliminating nitrogen have mainly been isolated from industrial and municipal wastewater, and they are usually used to treat wastewater [12,22]. Previous studies indicated that some aerobic denitrifying isolates had been successfully applied to treat aquaculture freshwater [13]. In this study, an aerobic denitrifying bacterium with high removal efficiency on nitrogen was isolated from an aquaculture pond. The strain belonged to the genus Bacillus according to the phylogenetic tree analysis. Moreover, the strain was a gram-positive bacterium with short rods. Thus, the isolated strain was identified as Bacillus sp. SC16.

When ammonia, nitrite, or nitrate were used as the sole nitrogen sources, strain SC16 showed a high removal efficiency and fast removal rate for all three inorganic nitrogen forms. The final removal rate of $\mathrm{NO}_{3}^{-}$-N by strain SC16 was $4.15 \mathrm{mg} \cdot \mathrm{L}^{-1} \mathrm{~h}^{-1}$, higher than that by Pseudomonas tolaasii Y-11 (1.99 mg. $\left.\mathrm{L}^{-1} \mathrm{~h}^{-1}\right)$ [25] and Klebsiella pneumoniae CF-S9 $\left(2.2 \mathrm{mg} \cdot \mathrm{L}^{-1} \mathrm{~h}^{-1}\right)$ [26], and similar to that by Ochrobactrum anthropi LJ81 $\left(4.16 \mathrm{mg} \cdot \mathrm{L}^{-1} \mathrm{~h}^{-1}\right)$ [17]. The final removal rate of ammonium by strain SC16 was $5.05 \mathrm{mg} \cdot \mathrm{L}^{-1} \mathrm{~h}^{-1}$, higher than that of some other denitrifiers such as P. stutzeri $\mathrm{T} 13$ 
$\left(3.98 \mathrm{mg} \cdot \mathrm{L}^{-1} \mathrm{~h}^{-1}\right)$ [27] and O. anthropi LJ81 $\left(3.84 \mathrm{mg} \cdot \mathrm{L}^{-1} \mathrm{~h}^{-1}\right)$ [17]. In addition, the removal rate of nitrite $\left(8.33 \mathrm{mg} \cdot \mathrm{L}^{-1} \mathrm{~h}^{-1}\right)$ was higher than those for nitrate and ammonium when SC16 was incubated with the three nitrogen sources, and the removal rate of nitrite by SC16 was also higher than those of Pseudomonas mendocina TJPU04 (1.85 mg. $\left.\mathrm{L}^{-1} \mathrm{~h}^{-1}\right)$ [28] and Arthrobacter arilaitensis Y-10 $\left(0.19 \mathrm{mg} \cdot \mathrm{L}^{-1}\right.$ $\mathrm{h}^{-1}$ ) [29]. Moreover, the majority of nitrogen was removed during the logarithmic phase of cell growth, and the maximal removal rates of nitrate, ammonia and nitrite achieved $20.50 \mathrm{mg} \cdot \mathrm{L}^{-1} \mathrm{~h}^{-1}$ at $12 \mathrm{~h}$, $5.05 \mathrm{mg} \cdot \mathrm{L}^{-1} \mathrm{~h}^{-1}$ at $12 \mathrm{~h}$, and $8.33 \mathrm{mg} \cdot \mathrm{L}^{-1} \mathrm{~h}^{-1}$ at $24 \mathrm{~h}$, respectively. The nitrogen removal rates decreased significantly after the logarithmic phase. This phenomenon was in agreement with the previous reports [17]. The reason might be that the nitrogen removal rates were inhibited by products released from bacteria, so that the concentrations of these inhibitors increased rapidly during the logarithmic phase due to the rapid growth of the bacteria, resulting in significant decreases in the removal rates. The removal efficiencies of nitrate and nitrite by SC16 reached $97 \%$ and $99.99 \%$, respectively, under aerobic conditions. Thus, the high removal performance of nitrogen by SC16 indicated that the strain had promising potential in aquaculture for the remediation of wastewater.

The characteristics of heterotrophic nitrification and aerobic denitrification had been demonstrated in other Bacillus spp., such as Bacillus methylotrophicus L7 [30], Bacillus litoralis N31 [31], and Bacillus subtilis A1 [12]. However, it has rarely reported in freshwater aquaculture. In the present work, the elimination of ammonia, nitrite, and nitrate suggested that nitrification and denitrification co-existed in strain SC16 under aerobic conditions. The following assay was conducted to investigate the activities of ammonia monooxygenase (AMO), nitrate reductase (NAR), and nitrite reductase (NIR). AMO was reported to be involved in the oxidation of ammonia to hydroxylamine. NAR and NIR are the key enzymes in the conversion of nitrate into nitrite and nitrite into nitric oxide, respectively. The present results indicated that AMO, NAR, and NIR coexisted in strain SC16, thus providing additional evidence of heterotrophic nitrification and aerobic denitrification by this strain.

As is well known, nitrite is harmful to aquatic animals due to its damage to the immune system and its interference with oxygen carrying in hemoglobin and hemocyanin [13]. In this study, SC16 grew well under a concentration of $200 \mathrm{mg} \cdot \mathrm{L}^{-1} \mathrm{NO}_{2}^{-}-\mathrm{N}$, with a high nitrite removal efficiency of $99.99 \%$ during 48 $\mathrm{h}$. The strain even survived under a concentration of $250 \mathrm{mg} \cdot \mathrm{L}^{-1} \mathrm{NO}_{2}^{-}-\mathrm{N}$, with a removal efficiency of $57.29 \%$. The results revealed that $\mathrm{SC} 16$ had a strong tolerance to nitrite. This phenomenon is consistent with the claims that aerobic denitrifiers usually tolerate high concentrations of nitrogen [32]. Moreover, there was almost no nitrite accumulation in DM-1 or DM-2. Similar results were also obtained for Acinetobacter sp. Y16 [33] and P. stutzeri D6 [34], which were no nitrite accumulation in Acinetobacter sp. Y16 treated group [33] and only trace accumulation of nitrite in P. stutzeri D6 treated group [34]. The concentration of $\mathrm{NO}_{2}^{-}-\mathrm{N}$ in SC16 was extremely lower than that in P. mendocina TJPU04 [28]. These results indicated the advantageous features of the SC16 strain in eliminating nitrite. Therefore, SC16 is a potential candidate biocontrol agent for eliminating nitrite.

Nitrite can be converted into nitrogenous compounds via three pathways: nitrite oxidation $\left(\mathrm{NO}_{2}^{-} \rightarrow \mathrm{NO}_{3}^{-}\right)$catalyzed by nitrite oxidoreductase in nitrification, reduction of nitrite to nitric oxide $\left(\mathrm{NO}_{2}^{-} \rightarrow \mathrm{NO}\right.$ ) catalyzed by nitrite reductase in denitrification, and reduction of nitrite to ammonium $\left(\mathrm{NO}_{2}^{-} \rightarrow \mathrm{NH}_{4}^{+}\right.$) catalyzed by nitrite reductase in dissimilation [35]. It has been reported that different pathways of removing nitrite are involved in different bacteria [25]. For example, A. faecalis No. 4 isolated from activated sludge could not remove $\mathrm{NO}_{2}^{-}-\mathrm{N}$ and $\mathrm{NO}_{3}^{-}-\mathrm{N}$ at the same time [36]. However, in the present study, $\mathrm{NO}_{2}^{-}-\mathrm{N}$ and $\mathrm{NO}_{3}^{-}-\mathrm{N}$ were present in the $\mathrm{DM}-2$, indicating that $\mathrm{NH}_{4}^{+}-\mathrm{N}$ was converted into $\mathrm{NO}_{2}^{-}-\mathrm{N}$ and $\mathrm{NO}_{3}^{-}-\mathrm{N}$ during nitrogen removal; $\mathrm{NO}_{2}^{-}-\mathrm{N}$ and $\mathrm{NH}_{4}^{+}-\mathrm{N}$ were detected in DM-1, and their concentrations decreased gradually, indicating that $\mathrm{NO}_{3}^{-}-\mathrm{N}$ was converted into $\mathrm{NO}_{2}^{-}-\mathrm{N}$ and subsequently degraded to $\mathrm{N}_{2}$ and $\mathrm{NH}_{4}^{+}-\mathrm{N} ; \mathrm{NO}_{3}^{-}-\mathrm{N}$ was accumulated in DM-3, indicating that $\mathrm{NO}_{2}^{-}-\mathrm{N}$ was converted into $\mathrm{NO}_{3}^{-}-\mathrm{N}$. These results indicated that the nitrogen removal pathway in strain SC16 included $\mathrm{NO}_{2}^{-} \rightarrow \mathrm{NO}_{3}^{-}, \mathrm{NO}_{2}^{-} \rightarrow \mathrm{NO}$, and $\mathrm{NO}_{2}^{-} \rightarrow \mathrm{NH}_{4}^{+}$. Therefore, the complete nitrification-denitrification process in strain $\mathrm{SC} 16$ was further confirmed as follows: $\mathrm{NH}_{4}^{+} \rightarrow \mathrm{NO}_{2}^{-} \rightarrow \mathrm{NO}_{3}^{-} \rightarrow \mathrm{NO}_{2}^{-} \rightarrow \mathrm{NO} \rightarrow \mathrm{N}_{2} \mathrm{O} \rightarrow \mathrm{N}_{2}$. In addition, the removal rate of nitrite 
was much higher than that of nitrate, and the accumulation of nitrite was lower than that of nitrate during the removal of ammonia, meaning that there might be partial nitrification-denitrification, i.e., $\mathrm{NH}_{4}^{+} \rightarrow \mathrm{NO}_{2}^{-} \rightarrow \mathrm{NO} \rightarrow \mathrm{N}_{2} \mathrm{O} \rightarrow \mathrm{N}_{2}$ [17].

The reduction of nitrite by NIR is the rate-limiting process of denitrification [37]. There are two entirely different NIR enzymes in terms of structure and the metal ion: one with heme cd1 (cd1-NIR) encoded by the nirS gene and the other containing copper (Cu-NIR) encoded by the nirK gene [38]. In this study, the nirK gene rather than the nirS gene was amplified from the Bacillus sp. SC16 genome. The result was consistent with the phenomenon that the two types of NIR do not co-exist in most denitrifiers [39]. The Cu-NIR is distributed extensively in gram-negative denitrifying bacteria, and its molecular structures have been well studied. However, Cu-NIR in gram-positive Bacillus sp. are rarely reported. Gao, et al. [40] reported molecular and structural analyses of Cu-NIR in gram-positive bacteria of Bacillus firmus GY-49. The present study provides further evidence for the existence of nirK in Bacillus sp.

The denitrification properties of bacteria are closely correlated to the functional gene encoding NIR, and there are many reports on the genes related to NIR [41]. The nirS gene has been demonstrated that it was more likely involved in aerobic denitrification, such as in Bacillus sp. YX-6 [19] and P. stutzeri ZF31 [42]. Recent studies have shown that the nirK gene was also related with denitrification [43] and detoxification [18]. Therefore, the quantitative PCR and enzyme assays were carried out to investigate whether NIR encoded by nirK gene was involved in denitrification in strain SC16. The results indicated that the expression levels of the nirK gene in sole nitrogen media were significantly higher than in the controls with no nitrogen source, demonstrating that the nirK gene was involved in the process of denitrification. However, the change in nirK expression did not maintain a pattern similar to the change in concentration of nitrite during the present tests. Previous work had shown that nitrogen resources could be captured into the pathway of assimilation in the process of denitrification [44]. It was speculated that some of the nitrogen resource could be assimilated into organic compounds. Additionally, the highest expression level of nirK was 4.89-fold in the nitrate medium, while the highest expression levels of nirK were 2.41-fold in nitrite medium and 2.90-fold in ammonia medium. These results indicated that nitrate was the more potent inducer for nirK gene expression.

Interestingly, a unique bimodal distribution of the expression of nirK was detected in sole nitrogen source media. The phenomenon was in agreement with the expression pattern of the nir gene in Marinobacter hydrocarbonoclasticus RAD-2 [45]. A suggested explanation was as follows: the expression level of nirK was up-regulated by nitrogen induction and reached its first peak during the process of nitrogen removal in DM-1, DM-2, and DM-3 media. In time, SC16 translated enough nitrite reductase to catalyze the conversion of substrates, and the excess nitrite reductase played a negative regulatory role on nirK gene expression. With the decrease of nitrite reductase, the expression of nirK was upregulated again and reached a second peak. The transcriptional pattern of the nirK gene was identical with the elimination of nitrate, ammonium, and nitrite in the process of denitrification. The similar expression pattern of the nirK gene in the presence of ammonium, nitrite, or nitrate as sole nitrogen sources indicated that both ammonium and nitrate were converted into nitrite, and then nitrite was converted into NO by NIR, demonstrating again the existence of HN-AD in this strain.

\section{Conclusions}

In this study, a heterotrophic nitrifying-aerobic denitrifying bacterium, Bacillus sp. SC16, was isolated from aquaculture ponds. Strain SC16 exhibited an enhanced ability remove nitrate, ammonia, and nitrite with high removal rates. The strain showed high tolerance against nitrite, and it grew well under the concentration of $250 \mathrm{mg} \cdot \mathrm{L}^{-1} \mathrm{NO}_{2}^{-}-\mathrm{N}$. It was demonstrated that adding strain SC16 to aquaculture wastewater could effectively reduce the nitrite. The nirK gene plays an important role in the elimination of residual nitrogen in water. Therefore, Bacillus sp. SC16 possesses highly practical application value in aquaculture water quality improvement. 
Supplementary Materials: The following are available online at http://www.mdpi.com/2073-4441/12/12/3559/s1, Table S1. The related primers for corresponding genes. Figure S1. The agarose gel electrophoresis of the qRT-PCR amplification product of nirK gene (lane 1) and 16S rRNA gene (lane 2) from strain SC16. Figure S2. Effects of carbon source (a), $\mathrm{C} / \mathrm{N}$ ratio (b), $\mathrm{pH}(\mathbf{c})$ and temperature (d) on the growth and nitrogen removal of strain SC16 under $60 \mathrm{~h}$ cultivation.

Author Contributions: Conceptualization, C.-G.S. and Q.-Z.Z.; funding acquisition, Q.-Z.Z.; investigation, C.-G.S., S.-Q.G. and J.-J.L.; methodology, C.-G.S., S.-Q.G. and J.-J.L.; data curation, C.-G.S.; project administration, Q.-Z.Z.; supervision, Q.-Z.Z.; writing-original draft preparation, C.-G.S. and Y.-W.F.; writing-review and editing, Y.-W.F. and Q.-Z.Z. All authors have read and agreed to the published version of the manuscript.

Funding: This research was funded by the Key-Area Research and Development Program of Guangdong Province (2019B020217001), as well as the Shellfish and Large Algae Industry Innovation Team Project of Guangdong Province (2020KJ146).

Acknowledgments: We also thank the editors and reviewers for the useful comments which greatly helped in improving the manuscript.

Conflicts of Interest: The authors declare no conflict of interest.

\section{References}

1. Cao, L.; Naylor, R.; Henriksson, P.; Leadbitter, D.; Metian, M.; Troell, M.; Zhang, W. China's aquaculture and the world's wild fisheries. Science 2015, 347, 133. [CrossRef] [PubMed]

2. Fishery Bureau, Ministry of Agriculture, People's Republic of China. China Fisheries Yearbook 2019; China Agriculture Press: Beijing, Chian, 2019.

3. Zhou, Q.; Takenaka, S.; Murakami, S.; Seesuriyachan, P.; Kuntiya, A.; Aoki, K. Screening and characterization of bacteria that can utilize ammonium and nitrate ions simultaneously under controlled cultural conditions. J. Biosci. Bioeng. 2007, 103, 185-191. [CrossRef] [PubMed]

4. Camargo, J.A.; Alonso, A. Ecological and toxicological effects of inorganic nitrogen pollution in aquatic ecosystems: A global assessment. Environ. Int. 2006, 32, 831-849. [CrossRef] [PubMed]

5. Crab, R.; Avnimelech, Y.; Defoirdt, T.; Bossier, P.; Verstraete, W. Nitrogen removal techniques in aquaculture for a sustainable production. Aquaculture 2007, 270, 1-14. [CrossRef]

6. Chen, P.; Li, J.; Li, Q.X.; Wang, Y.; Li, S.; Ren, T.; Wang, L. Simultaneous heterotrophic nitrification and aerobic denitrification by bacterium Rhodococcus sp. CPZ24. Bioresour. Technol. 2012, 116, 266-270. [CrossRef]

7. Robertson, L.A.; Kuenen, J.G. Combined heterotrophic nitrification and aerobic denitrification in Thiosphaera pantotropha and other bacteria. Antonie Leeuwenhoek 1990, 57, 139-152. [CrossRef]

8. Padhi, S.K.; Tripathy, S.; Mohanty, S.; Maiti, N.K. Aerobic and heterotrophic nitrogen removal by Enterobacter cloacae CF-S27 with efficient utilization of hydroxylamine. Bioresour. Technol. 2017, 232, 285-296. [CrossRef]

9. Kim, M.; Jeong, S.Y.; Yoon, S.J.; Cho, S.J.; Kim, Y.H.; Kim, M.J.; Ryu, E.Y.; Lee, S.J. Aerobic denitrification of Pseudomonas putida AD-21 at different C/N ratios. J. Biosci. Bioeng. 2008, 106, 498-502. [CrossRef]

10. Joo, H.S.; Hirai, M.; Shoda, M. Piggery wastewater treatment using Alcaligenes faecalis strain No. 4 with heterotrophic nitrification and aerobic denitrification. Water Res. 2006, 40, 3029-3036. [CrossRef]

11. Su, J.J.; Liu, B.Y.; Liu, C.Y. Comparison of aerobic denitrification under high oxygen atmosphere by Thiosphaera pantotropha ATCC 35512 and Pseudomonas stutzeri SU2 newly isolated from the activated sludge of a piggery wastewater treatment system. J. Appl. Microbiol. 2001, 90, 457-462. [CrossRef]

12. Yang, X.P.; Wang, S.M.; Zhang, D.W.; Zhou, L.X. Isolation and nitrogen removal characteristics of an aerobic heterotrophic nitrifying-denitrifying bacterium, Bacillus subtilis A1. Bioresour. Technol. 2011, 102, 854-862. [CrossRef] [PubMed]

13. Gao, J.; Gao, D.; Liu, H.; Cai, J.; Zhang, J.; Qi, Z. Biopotentiality of high efficient aerobic denitrifier Bacillus megaterium S379 for intensive aquaculture water quality management. J. Environ. Manag. 2018, 222, 104-111. [CrossRef] [PubMed]

14. Zumft, W.G. Cell biology and molecular basis of denitrification. Microbiol. Mol. Biol. R. 1997, 61, 533-616. [CrossRef]

15. Rajta, A.; Bhatia, R.; Setia, H.; Pathania, P. Role of heterotrophic aerobic denitrifying bacteria in nitrate removal from wastewater. J. Appl. Microbiol. 2020, 128, 1261-1278. [CrossRef] [PubMed] 
16. Li, C.; Yang, J.; Wang, X.; Wang, E.; Li, B.; He, R.; Yuan, H. Removal of nitrogen by heterotrophic nitrification-aerobic denitrification of a phosphate accumulating bacterium Pseudomonas stutzeri YG-24. Bioresour. Technol. 2015, 182, 18-25. [CrossRef] [PubMed]

17. Lei, X.; Jia, Y.; Chen, Y.; Hu, Y. Simultaneous nitrification and denitrification without nitrite accumulation by a novel isolated Ochrobactrum anthropic LJ81. Bioresour. Technol. 2019, 272, 442-450. [CrossRef]

18. Wittorf, L.; Jones, C.M.; Bonilla-Rosso, G.; Hallin, S. Expression of nirK and nirS genes in two strains of Pseudomonas stutzeri harbouring both types of NO-forming nitrite reductases. Res. Microbiol. 2018, 169, 343-347. [CrossRef]

19. Song, Z.F.; An, J.; Fu, G.H.; Yang, X.L. Isolation and characterization of an aerobic denitrifying Bacillus sp. YX-6 from shrimp culture ponds. Aquaculture 2011, 319, 188-193. [CrossRef]

20. Zhao, B.; He, Y.L.; Huang, J.; Taylor, S.; Hughes, J. Heterotrophic nitrogen removal by Providencia rettgeri strain YL. J. Ind. Microbiol. Biotechnol. 2010, 37, 609-616. [CrossRef]

21. Lowry, O.H.; Rosebrough, N.J.; Farr, A.L.; Randall, R.J. Protein measurement with the Folin phenol reagent. J. Biol. Chem. 1951, 193, 265-275. [CrossRef]

22. Yang, L.; Ren, Y.X.; Zhao, S.Q.; Liang, X.; Wang, J.P. Isolation and characterization of three heterotrophic nitrifying-aerobic denitrifying bacteria from a sequencing batch reactor. Ann. Microbiol. 2015, 66, 737-747. [CrossRef]

23. Chomczynski, P.; Sacchi, N. Single-step method of RNA isolation by acid guanidinium thiocyanate-phenol-chloroform extraction. Anal. Biochem. 1987, 162, 156-159. [CrossRef]

24. APHA. Standard Methods for the Examination of Water and Wastewater, 19th ed.; American Public Health Association: Washington, DC, USA, 1985.

25. He, T.; Li, Z.; Sun, Q.; Xu, Y.; Ye, Q. Heterotrophic nitrification and aerobic denitrification by Pseudomonas tolaasii Y-11 without nitrite accumulation during nitrogen conversion. Bioresour. Technol. 2016, 200, 493-499. [CrossRef] [PubMed]

26. Padhi, S.K.; Tripathy, S.; Sen, R.; Mahapatra, A.S.; Mohanty, S.; Maiti, N.K. Characterisation of heterotrophic nitrifying and aerobic denitrifying Klebsiella pneumoniae CF-S9 strain for bioremediation of wastewater. Int. Biodeter. Biodegr. 2013, 78, 67-73. [CrossRef]

27. Sun, Y.; Li, A.; Zhang, X.; Ma, F. Regulation of dissolved oxygen from accumulated nitrite during the heterotrophic nitrification and aerobic denitrification of Pseudomonas stutzeri T13. Appl. Microbiol. Biot. 2015, 99, 3243-3248. [CrossRef]

28. He, X.; Sun, Q.; Xu, T.; Dai, M.; Wei, D. Removal of nitrogen by heterotrophic nitrification-aerobic denitrification of a novel halotolerant bacterium Pseudomonas mendocina TJPU04. Bioproc. Biosyst. Eng. 2019, 42, 853-866. [CrossRef]

29. He, T.; Xie, D.; Li, Z.; Ni, J.; Sun, Q. Ammonium stimulates nitrate reduction during simultaneous nitrification and denitrification process by Arthrobacter arilaitensis Y-10. Bioresour. Technol. 2017, 239, 66-73. [CrossRef]

30. Zhang, Q.L.; Liu, Y.; Ai, G.M.; Miao, L.L.; Zheng, H.Y.; Liu, Z.P. The characteristics of a novel heterotrophic nitrification-aerobic denitrification bacterium, Bacillus methylotrophicus strain L7. Bioresour. Technol. 2012, 108, 35-44. [CrossRef]

31. Huang, F.; Pan, L.; Lv, N.; Tang, X. Characterization of novel Bacillus strain N31 from mariculture water capable of halophilic heterotrophic nitrification-aerobic denitrification. J. Biosci. Bioeng. 2017, 124, 564-571. [CrossRef]

32. Guo, L.; Chen, Q.; Fang, F.; Hu, Z.; Wu, J.; Miao, A.; Xiao, L.; Chen, X.; Yang, L. Application potential of a newly isolated indigenous aerobic denitrifier for nitrate and ammonium removal of eutrophic lake water. Bioresour. Technol. 2013, 142, 45-51. [CrossRef]

33. Huang, X.; Li, W.; Zhang, D.; Qin, W. Ammonium removal by a novel oligotrophic Acinetobacter sp. Y16 capable of heterotrophic nitrification-aerobic denitrification at low temperature. Bioresour. Technol. 2013, 146, 44-50. [CrossRef] [PubMed]

34. Yang, X.; Wang, S.; Zhou, L. Effect of carbon source, $\mathrm{C} / \mathrm{N}$ ratio, nitrate and dissolved oxygen concentration on nitrite and ammonium production from denitrification process by Pseudomonas stutzeri D6. Bioresour. Technol. 2012, 104, 65-72. [CrossRef] [PubMed]

35. Kaspar, H.F.; Tiedje, J.M.; Firestone, R.B. Denitrification and dissimilatory nitrate reduction to ammonium in digested sludge. Can. J. Microbiol. 1981, 27, 878-885. [CrossRef] [PubMed] 
36. Joo, H.S.; Hirai, M.; Shoda, M. Characteristics of ammonium removal by heterotrophic nitrification-aerobic denitrification by Alcaligenes faecalis No. 4. J. Biosci. Bioeng. 2005, 100, 184-191. [CrossRef]

37. Doi, Y.; Takaya, N.; Takizawa, N. Novel denitrifying bacterium Ochrobactrum anthropi YD50.2 tolerates high levels of reactive nitrogen oxides. Appl. Environ. Microb. 2009, 75, 5186-5194. [CrossRef] [PubMed]

38. Brittain, T.; Blackmore, R.; Greenwood, C.; Thomson, A.J. Bacterial nitrite-reducing enzymes. Eur. J. Biochem. 1992, 209, 793-802. [CrossRef]

39. Vaccaro, B.J.; Thorgersen, M.P.; Lancaster, W.A.; Price, M.N.; Wetmore, K.M.; Poole, F.L.; Deutschbauer, A.; Arkin, A.P.; Adams, M.W. Determining roles of accessory genes in denitrification by mutant fitness analyses. Appl. Environ. Microb. 2016, 82, 51-61. [CrossRef]

40. Gao, H.; Li, C.; Ramesh, B.; Hu, N. Cloning, purification and characterization of novel Cu-containing nitrite reductase from the Bacillus firmus GY-49. World J. Microb. Biot. 2017, 34, 10. [CrossRef]

41. Braker, G.; Zhou, J.; Wu, L.; Devol, A.H.; Tiedje, J.M. Nitrite reductase genes (nirK and nirS) as functional markers to investigate diversity of denitrifying bacteria in pacific northwest marine sediment communities. Appl. Environ. Microb. 2000, 66, 2096-2104. [CrossRef]

42. Huang, T.; Guo, L.; Zhang, H.; Su, J.; Wen, G.; Zhang, K. Nitrogen-removal efficiency of a novel aerobic denitrifying bacterium, Pseudomonas stutzeri strain ZF31, isolated from a drinking-water reservoir. Bioresour. Technol. 2015, 196, 209-216. [CrossRef]

43. Wan, C.; Yang, X.; Lee, D.-J.; Du, M.; Wan, F.; Chen, C. Aerobic denitrification by novel isolated strain using NO2-N as nitrogen source. Bioresour. Technol. 2011, 102, 7244-7248. [CrossRef] [PubMed]

44. Jin, P.; Chen, Y.; Yao, R.; Zheng, Z.; Du, Q. New insight into the nitrogen metabolism of simultaneous heterotrophic nitrification-aerobic denitrification bacterium in mRNA expression. J. Hazard. Mater. 2019, 371, 295-303. [CrossRef] [PubMed]

45. Kong, D.; Li, W.; Deng, Y.; Ruan, Y.; Chen, G.; Yu, J.; Lin, F. Denitrification potential evaluation and nitrate-removal-pathway analysis of aerobic denitrifier strain Marinobacter hydrocarbonoclasticus RAD-2. Water 2018, 10, 1298. [CrossRef]

Publisher's Note: MDPI stays neutral with regard to jurisdictional claims in published maps and institutional affiliations.

(C) 2020 by the authors. Licensee MDPI, Basel, Switzerland. This article is an open access article distributed under the terms and conditions of the Creative Commons Attribution (CC BY) license (http://creativecommons.org/licenses/by/4.0/). 